\title{
Effect of water stress on the behavior of six durum wheat genotypes in a semi-arid region of western Algeria
}

\author{
Fetati $A^{1 *}$, Mediouni R.M², Benseddik $B^{3}$, Abbache $A^{4}$, Zaagane $\mathbf{M}^{5}$ \\ 1Department of Biology, Faculty of Natural and Life Sciences, Mustapha Stambouli University of \\ Mascara, Laboratory of Research on Biological Systems and on Geomatics (LRSBG), Algeria. \\ 2Laboratory of Physiology, Physiopathology and Biochemistry of Nutrition (PPABIONUT), Faculty of \\ Natural and Life Sciences, Abou-Bekr Belkaïd Tlemcen University, Algeria. \\ 3 Faculty of Natural and Life Sciences, Djilali Liabes University of Sisdi bel Abbes, Algeria. \\ 4 Department of Biology, Faculty of Natural and Life Sciences, Mustapha Stambouli University of \\ Mascara, \\ Laboratory of Stratigraphic Paleontology and Paleoenvironmnt, Mohamed Ben Hmed University, \\ Oran2, Algeria.
}

* Corresponding Author: Fetati Aicha, Mustapha Stambouli University of Mascara, Algeria. Email: a.fetati@univ-mascara.dz

\begin{abstract}
Six genotypes of durum wheat (Triticum turgidum L. subsp. durum (Desf.) Husn.) were investigated under different watering regimes. Phenological and morphological parameters as well as some yield components were monitored. The results showed that: (1) the water deficit significantly affects the height of the plants, the length and the weight of the spikes. (2) Irrigation has a significant effect on all of the yield components. Doses of $39 \mathrm{~mm}$ at tillering, $60 \mathrm{~mm}$ at stem elongation and $30 \mathrm{~mm}$ at heading stage achieved the best yields. (3) Earliness at heading and at maturity is an important factor in determining the adaptation to water stress and in obtaining a good yield. (4) Under favorable irrigation conditions precocious and semi-precocious selected varieties have been shown to be more productive and even adapted to the water stress of the region. (5) The productivity of the durum wheat crop is imperatively based on the choice of a tolerant genotype to the conditions of the region on the one hand and on the use of supplementary irrigation on the other hand, especially at the vegetative stage where the yield component is the most determining, in our case it seems to be the populating spike carried out at the booting stage.
\end{abstract}

Keywords: Durum wheat, genotypes, precocity, water deficit, semi-arid region

\section{Introduction}

In Algeria, which is part of the Mediterranean zone where arid and semi-arid bioclimates prevail and water is most often the main factor limiting the extension of cereal cultivation. The production is characterized by fluctuations which vary from year to year, and the drought remains the main cause of this situation. Two major constraints seem to be at the origin of this state, the rainfall interannual variations (Belaid et al., 2012) as well as rainfall distribution over time: too often, springs show a rainfall deficit. During this period, cereals are subjected to water stress which results in a drop in yield. It affects all aspects of growth. It is reflected in the plant by a series of modifications which affect the morphophysiological, biochemical, genetic characters and even the levels of expression of genes associated with drought (Mefti et al., 2000). Water supplies during this period allow the crop to best express its growth and development, beyond that, obtaining good production.

Furthermore, many researchers have focused their investigations in particular on the selection of adapted varieties to these regions with high water stress, either by genetic improvement which remains, 
Fetati et al. 2021. Genet. Biodiv. J, Special issue (Characterization and valorisation of Plants), 77-92

without doubt, the most effective means or by an in-depth study of the various adaptation mechanisms (Hsissou, et Bouharmont, 1994 ; El Hafid et al., 1998 ; Mekhlouf et al., 2006 ; Talebi et al., 2009 ; Monneveux et al., 2012 ; Hacini et Brinis, 2012 ; Boussakouran et al., 2019 ; PourAboughadareh etal.,2020 Honsdorf et al., 2020). This study fits in this direction and aims to define the vegetation period during which durum wheat enhances irrigation by describing the variability of morphological characters towards water stress.

\section{Materials and methods}

\section{Experimental site}

The tests were carried out in the experimental site of the Technical Institute of Field Crops located 3

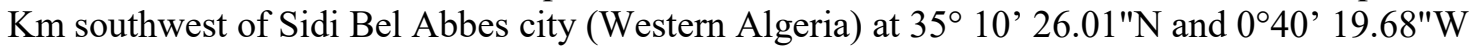
elevated at $486 \mathrm{~m}$, during the campaign 1997-1998, situated in the semi-arid bioclimate and characterized by a sandy loam soil.

\section{Plant material}

Six durum genotypes (Triticum turgidum L. subsp. durum) have been the subject of several measures (View table 3). These are late local and selected precocious and semi-precocious genotypes (Table1).

Table 1. The used genotypes

\begin{tabular}{lll}
\hline Genotype & Origin & Precocity \\
\hline Oued Zenati & local & late \\
\hline Chen's" & selected & Precocious \\
\hline BD 1/94 & selected & semi- precocious \\
\hline Oum Rabi 9 & selected & semi- precocious \\
\hline Kabir & selected & semi- precocious \\
\hline Med Ben Bachir & local & Late \\
\hline
\end{tabular}

\section{Experimental design}

Set-up: Seeds were laid down in randomized blocks design with three replications (Table 2).

Dry and irrigated treatments (Table 3) were carried out on the same plot to avoid the heterogeneity effect of the soil.

Table 2. Experimental design of the study

\begin{tabular}{llll}
\hline Genotype & \multicolumn{3}{l}{ Randomization } \\
\hline Oued Zenati (O.Z) & 1 & 8 & 14 \\
\hline Chen's' (CH.S) & 2 & 10 & 17 \\
\hline Bd 1/94 (BD 1/94) & 3 & 11 & 15 \\
\hline Om Rabi 9 (O.R.9) & 4 & 7 & 18 \\
\hline Kabir (KAB) & 5 & 12 & 16 \\
\hline Med Ben Bachir (MB.B) & 6 & 9 & 13 \\
\hline
\end{tabular}

Seeding rate was 250 viable seeds $/ \mathrm{m}^{2}$ (semi-arid zone) and the sowing was carried out with an experimental seeder on:

- 36 elementary plots.

- Elementary plot area: $1.20 \mathrm{~cm} . * 5 \mathrm{~m} .\left(6 \mathrm{~m}^{2}\right)$.

- Number of lines: 6.

- Spacing between lines: $20 \mathrm{~cm}$.

- Distance between blocks: $1 \mathrm{~m}$.

Previous: fallow; 1st re-crossing on October 2nd re-crossing in November; Weeding: 2.4.D at the rate of 11 / ha. 
Fetati et al. 2021. Genet. Biodiv. J, Special issue (Characterization and valorisation of Plants), 77-92

Measurement of soil moisture: soil moisture for the two tests (irrigated and dry) was measured weekly by taking samples at three depths $(10,20$ and $30 \mathrm{~cm}$.) (Table 3$)$.

Measures and data analysis

Table 3. Rainfall, irrigation, and soil moisture

\begin{tabular}{|c|c|c|c|c|c|c|c|}
\hline \multirow[b]{2}{*}{ Months } & \multirow[b]{2}{*}{ Decades } & \multirow[b]{2}{*}{$\begin{array}{l}\text { Rainfall } \\
(\mathbf{m m})\end{array}$} & \multirow{2}{*}{$\begin{array}{l}\text { Soil } \\
\text { moisture } \\
(\%)\end{array}$} & \multirow[b]{2}{*}{ Vegetative stage } & \multicolumn{3}{|c|}{ Irrigation (mm of water) } \\
\hline & & & & & $\begin{array}{l}\text { 50\% Field } \\
\text { capacity }\end{array}$ & $\begin{array}{l}3 \\
\text { stages }\end{array}$ & $\begin{array}{l}3 \text { stages } \\
28-25-25 \\
\end{array}$ \\
\hline \multirow{3}{*}{ Sep. } & $1-10$ & 0 & - & & & & \\
\hline & $11-20$ & 31.6 & - & & & & \\
\hline & $21-30$ & 49 & - & & & & \\
\hline \multirow{3}{*}{ Oct. } & $1-10$ & 12.2 & 20.8 & & & & \\
\hline & $11-20$ & 3 & 20.9 & & & & \\
\hline & $21-31$ & 18 & 19.4 & & & & \\
\hline \multirow{3}{*}{ Nov. } & $1-10$ & 3.5 & 16.8 & & & & \\
\hline & $11-20$ & 19.2 & 14.7 & & & & \\
\hline & $21-30$ & 37.1 & 16 & & & & \\
\hline \multirow{3}{*}{ Dec. } & $1-10$ & 17.9 & 17.6 & \multirow{3}{*}{$\begin{array}{l}\text { Sowing: } \\
17 / 12\end{array}$} & & & \\
\hline & $11-20$ & 43.8 & 17.2 & & & & \\
\hline & $21-31$ & 7 & 16.7 & & & & \\
\hline \multirow{3}{*}{ Jan. } & $1-10$ & 10 & 16.7 & \multirow{3}{*}{$\begin{array}{l}\text { Emergence: } \\
03 / 01\end{array}$} & \multirow{3}{*}{$\begin{array}{l}24 \mathrm{~mm} \\
21 / 01\end{array}$} & & \\
\hline & $11-20$ & 00 & 14.4 & & & & \\
\hline & $21-30$ & 5.7 & 12.5 & & & & \\
\hline \multirow{3}{*}{ Feb. } & $1-10$ & 46.3 & 18.5 & \multirow{3}{*}{$\begin{array}{l}\text { Tillering: from } \\
01 / 02 \text { to } 02 / 02\end{array}$} & \multirow{3}{*}{$\begin{array}{l}12 \mathrm{~mm} \mathrm{09/02} \\
27 \mathrm{~mm} \mathrm{21/02}\end{array}$} & $20 \mathrm{~mm}$ & \multirow{3}{*}{$\begin{array}{l}28 \mathrm{~mm} \\
28 / 02\end{array}$} \\
\hline & $11-20$ & 2.5 & 13.6 & & & $18 / 02$ & \\
\hline & $21-29$ & 0 & 11.1 & & & $\begin{array}{l}30 \mathrm{~mm} \\
26 / 02\end{array}$ & \\
\hline \multirow{3}{*}{ Mar. } & $1-10$ & 0 & 9.6 & \multirow{3}{*}{$\begin{array}{l}\text { Booting- sweling } \\
09 / 03-19 / 03\end{array}$} & \multirow{3}{*}{$\begin{array}{l}32 \mathrm{~mm} \mathrm{09/03} \\
28 \mathrm{~mm} \mathrm{19/03}\end{array}$} & & \multirow{3}{*}{$\begin{array}{l}25 \mathrm{~mm} \\
24 / 03\end{array}$} \\
\hline & $11-20$ & 5.5 & 9.2 & & & - & \\
\hline & $21-31$ & 7.5 & 7.2 & & & & \\
\hline \multirow{3}{*}{ Apr. } & $1-10$ & 14.2 & 7.1 & \multirow{3}{*}{$\begin{array}{l}\text { Heading } \\
\text { Flowering 08/04 } \\
\text { 20/04 }\end{array}$} & \multirow{3}{*}{$\begin{array}{l}30 \mathrm{~mm} \\
14 / 04\end{array}$} & \multirow{3}{*}{$\begin{array}{l}20 \mathrm{~mm} \\
08 / 04 \\
30 \mathrm{~mm} \\
13 / 04\end{array}$} & \\
\hline & $11-20$ & 0 & 9.5 & & & & \\
\hline & $21-30$ & 8.8 & 8.6 & & & & \\
\hline \multirow{3}{*}{ May } & $1-10$ & 27 & 11.2 & \multirow{3}{*}{$\begin{array}{l}\text { Grain filling } \\
04 / 05\end{array}$} & \multirow{3}{*}{$22 \mathrm{~mm} \mathrm{06/05}$} & $28 \mathrm{~mm}$ & \\
\hline & $11-20$ & 4.5 & 7.2 & & & $05 / 05$ & $25 \mathrm{~mm}$ \\
\hline & $21-31$ & 7.3 & 6.7 & & & $\begin{array}{l}22 \mathrm{~mm} \\
10 / 05\end{array}$ & $05 / 05$ \\
\hline & $1-10$ & 0 & 7.3 & Maturity Harvest & & & \\
\hline June & $11-20$ & 4.5 & 6.8 & $10 / 06$ & - & - & \\
\hline & $21-30$ & 0 & 6.3 & $16 / 06$ & & & \\
\hline Total & & 377.2 & 343.6 & & 175 & 150 & 78 \\
\hline
\end{tabular}

Phenological, morphological and yield components measurements (Table 4) were analyzed using standard ANOVA where treatment means were compared using the Honestly Significant Difference (HSD) method, additionally a coefficient of variation (CV) was calculated for each analysis to adjust the variability in the data to be assessed, in the same contrast, correlation matrices are used to derive the relationships between characteristics of durum wheat. Correlation coefficients were applied according to Pearson's method, the aim of correlation is to test relations between the different types of measures parameters, the statistical analysis was carried out using $\mathrm{R}$ software version 3.6.3 (R Core Team 2020). 


\section{Results and discussion}

\section{Morphological traits}

\section{Number of plants per $m^{2}$}

The analysis of variance shows that the test is fairly reliable (cv $=7.3 \%$ in dryness and $10.6 \%$ in watered). The values of the Fischer test calculated for the two tests are slightly higher than the theoretical value of F (2.77) which leads to say that the differences between the varieties are barely significant. The DUNNET test treating the dry test shows that Kabir and Chen's are significantly superior to the control (Oued Zenati), noting that Kabir records the best average $\left(229.17 \mathrm{plants} / \mathrm{m}^{2}\right)$ and BD 1/94 the lowest one (162.50 plants/m²). While these same genotypes (Kabir and Chen's ') are equal to the control in the irrigated trial where Chen's' records the best average $\left(246 \mathrm{plants} / \mathrm{m}^{2}\right)$ and BD 1/94 records the lowest average $\left(170\right.$ plants $\left./ \mathrm{m}^{2}\right)$ and it is the only genotype significantly inferior to the control (Table 5).

Concerning this parameter, between the tested genotypes, the difference was not very significant, however, the irrigated tests gave more important stands (Figure 9).

Table 4. Monitored parameters in dry and irrigated tests.

\begin{tabular}{|c|c|}
\hline Parameters & Irrigated (Ir) and rainy conditions (Dry) \\
\hline \multirow[t]{9}{*}{ Morphological } & Number of plants per $\mathrm{m}^{2}\left(\mathrm{NP} / \mathrm{m}^{2}\right)$ \\
\hline & Number of tillers per $\mathrm{m}^{2}\left(\mathrm{Nti} / \mathrm{m}^{2}\right)$ \\
\hline & Number of spiky tillers per $\mathrm{m}^{2}\left(\mathrm{Nst} / \mathrm{m}^{2}\right)$ \\
\hline & Plant height in $\mathrm{cm}(\mathrm{Ph})$ \\
\hline & Ear length in $\mathrm{cm}(\mathrm{Ls})$ \\
\hline & Beard length in $\mathrm{cm}(\mathrm{Lb})$; \\
\hline & Ear neck length in $\mathrm{cm}\left(\mathrm{Lsn} / \mathrm{m}^{2}\right)$ \\
\hline & Length of last internode in $\mathrm{cm}$ (LLi); \\
\hline & Senescence $(\mathrm{S})$ \\
\hline \multirow[t]{2}{*}{ Phenological } & Days to heading ; \\
\hline & Days to maturity; \\
\hline \multirow{9}{*}{$\begin{array}{l}\text { Yield } \\
\text { components }\end{array}$} & Number of ears per $\mathrm{m}^{2}\left(\mathrm{Ns} / \mathrm{m}^{2}\right)$ \\
\hline & Number of fertile spikelets per ear (NfsH) \\
\hline & Number of grains per ear $(\mathrm{NgS})$ \\
\hline & Ear weight in $\mathrm{Gr}(\mathrm{Sw})$ \\
\hline & Grain weight in $\mathrm{Gr}(\mathrm{GW})$ \\
\hline & Thousand grain weight in Gr (Thgw); \\
\hline & Biological yield in Qs/ha(By); \\
\hline & Grain yield in Qs/ha(GY); \\
\hline & Harvest index (HI) \\
\hline
\end{tabular}


Fetati et al. 2021. Genet. Biodiv. J, Special issue (Characterization and valorisation of Plants), 77-92

Table 5. DUNNET test of the number of plants per $\mathrm{m}^{2}$ of the tested durum wheat genotypes under watered and non-watered conditions

\begin{tabular}{ll}
\hline Genotypes & Averages \\
\hline Kabir & 229.17 \\
\hline Chen's' & $215.83>$ control \\
\hline M.B. Bachir & 208.33 \\
\hline Om Rabi 9 & 189.17 \\
\hline Oued Zenati & $180.00=$ control \\
\hline BD 1/94 & 162.50 \\
\hline
\end{tabular}

\begin{tabular}{ll}
\hline Genotypes & Averages \\
\hline Chen's' & $\mathbf{2 4 6 . 0 0}$ \\
\hline Oued Zenati & $\mathbf{2 3 7 . 5 0}=$ control \\
\hline M.B. Bachir & $\mathbf{2 1 3 . 3 3}$ \\
\hline Kabir & $\mathbf{2 0 9 . 1 7}$ \\
\hline Om Rabi 9 & $\mathbf{2 0 5 . 0 0}$ \\
\hline BD 1/94 & $\mathbf{1 7 0 . 0 0}<$ control \\
\hline
\end{tabular}

Number of tillers per $m 2$

Statistical analysis reveals variability between genotypes. The differences are highly significant. BD 1/94 represents the lowest number of tillers per $\mathrm{m}^{2}$ according to the DUNNET test. This is a selected genotype that was shown to be significantly inferior to the control under rainy conditions, while it is equal to the control under irrigation conditions. Kabir has the best tillering coefficient. Noting that MB Bachir, Oued Zenati and Chen's' had, in rainy conditions, have more tillers per $\mathrm{m}^{2}$ than those recorded under irrigation conditions (Figure1), this can be traced to the negative effect of the frost which affected the soil knowing that 4 days of frost marked the month of February.

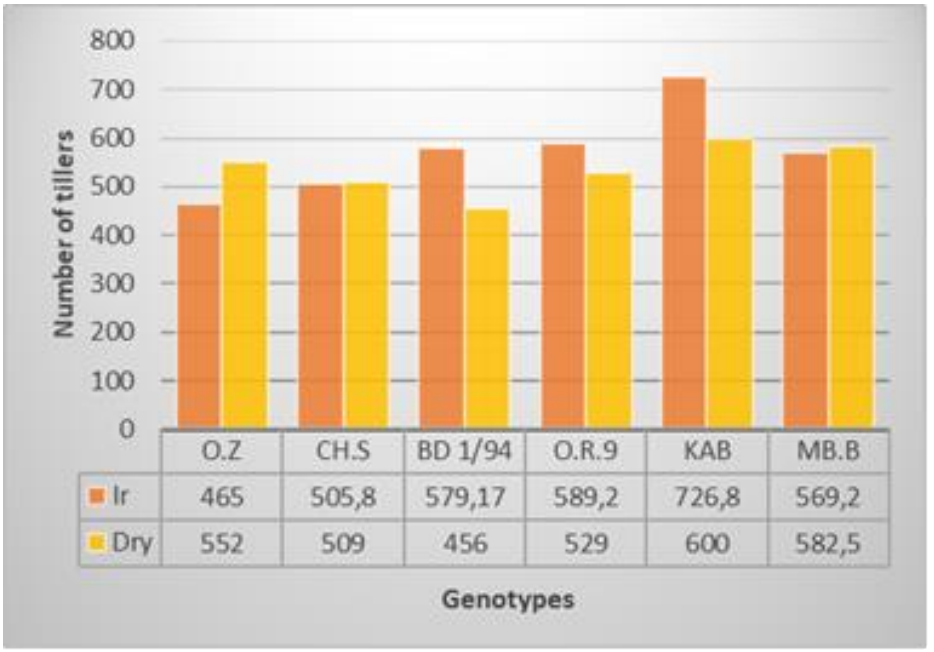

Figure 1. Number of tillers per $\mathrm{m}^{2}$ of the tested durum wheat genotypes under watered and nonwatered conditions

Kabir has the best tillering coefficient under irrigation conditions. Note that the number of tillers is correlated with the number of plants $/ \mathrm{m}^{2}$ (Figure 9). An important correlation has been showed between the number of ears and the grain yield $\left(\mathrm{r}^{2}=0.944\right)$ in dry and $\left(\mathrm{r}^{2}=0.723\right)$ in irrigated.

Number of spiky tillers per $m^{2}$

There is not a significant difference between the tested genotypes. However, a difference between the two treatments, this is proven by the DUNNET test (Table 6). Chen's 'and Kabir are significantly superior to the control in the dry test, while only BD 1/94 is superior to Oued Zenati with the best average in watered conditions. 
Fetati et al. 2021. Genet. Biodiv. J, Special issue (Characterization and valorisation of Plants), 77-92

Table 6. DUNNET test of spiky tillers per $\mathrm{m}^{2}$ of the tested durum wheat genotypes under watered and non-watered conditions

\begin{tabular}{ll}
\hline Genotypes & Averages \\
\hline Chen's' & $287.50 \quad>$ control \\
\hline Kabir & $271.67>$ control \\
\hline BD 1/94 & 247.50 \\
\hline Om Rabi 9 & 238.33 \\
\hline Oued Zenati & $212.50=$ control \\
\hline M.B. Bachir & 206.67 \\
\hline
\end{tabular}

\begin{tabular}{ll}
\hline Genotypes & Averages \\
\hline BD 1/94 & $415.00>$ control \\
\hline Om Rabi 9 & 335.00 \\
\hline Kabir & 320.83 \\
\hline Chen's' & 308.33 \\
\hline Oued Zenati & $273.50=$ control \\
\hline M.B. Bachir & 271.67 \\
\hline
\end{tabular}

\section{Plant height}

The results indicate little variability between genotypes, the DUNNET test illustrates the efficiency of irrigation on height. The average height of plants under rainy conditions is $65.49 \mathrm{~cm}$ and in watered conditions is $97.58 \mathrm{~cm}$. Plant height is a useful physiological trait in breeding studies for the identification of stress tolerant genotypes under drought conditions. In relation to this characteristic, we note that the local genotypes (Oued Zenati and M.B. Bachir) record the best averages in both conditions, Om rabi 9 which a selected genotype is the most sensitive one. It is therefore estimated that these two local genotypes will generate a very high yield (in straw) compared to the selected varieties all belonging to a second group of averages significantly lower than the control (in irrigated conditions) (Figure 2).

Statistical analysis did not show a large difference between the two conditions. In the dry trial, the DUNNET test divides the varieties into two groups, the first grouping Kabir and Chen's 'which are significantly superior to the control, and the second grouping genotypes equal to the control. In the watered test, we have two groups where BD 1/94 records the longest ears $(6.47 \mathrm{~cm})$ and it is significantly greater than the control. The other genotypes have means significantly equal to the control (Table 7).

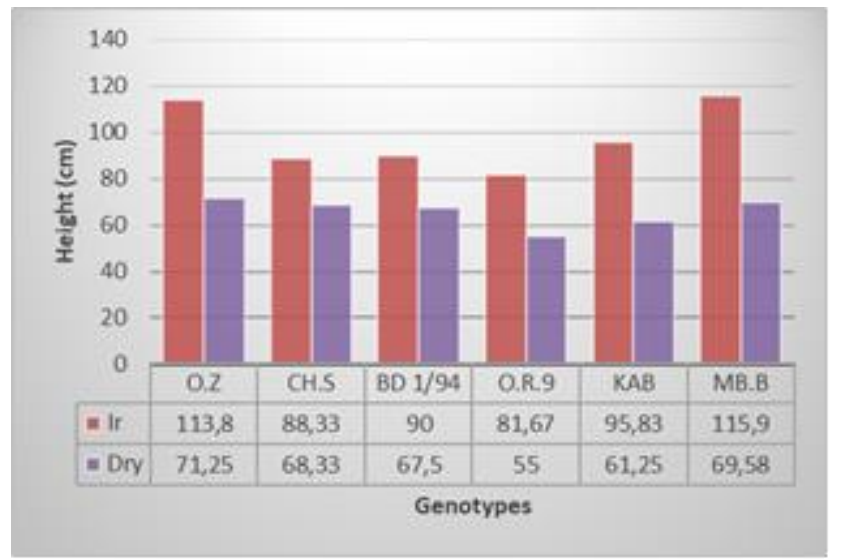

Figure 2. Plant height $(\mathrm{cm})$ of the tested durum wheat genotypes under watered and non-watered conditions

\section{Ear length}

Table 7 DUNNET test of the ear lengh of the tested durum wheat genotypes under watered and nonwatered conditions.

\begin{tabular}{lll}
\hline Variétés & Moyennes \\
\hline Kabir & $6.57 \quad>$ témoin \\
\hline Chen's' & $5.83 \quad$ > témoin \\
\hline BD 1/94 & 5.63 & \\
\hline Om Rabi 9 & 5.20 & \\
\hline M.B. Bachir & 5.10 & \\
\hline Oued Zenati & $4.73 \quad$ = témoin \\
\hline
\end{tabular}

\begin{tabular}{ll}
\hline Variétés & Moyennes \\
\hline BD 1/94 & $6.47>$ témoin \\
\hline Chen's' & 6.13 \\
\hline Kabir & 5.90 \\
\hline Om Rabi 9 & 5.63 \\
\hline Oued Zenati & $4.90=$ témoin \\
\hline M.B. Bachir & 4.23 \\
\hline
\end{tabular}

Beards length 
Fetati et al. 2021. Genet. Biodiv. J, Special issue (Characterization and valorisation of Plants), 77-92

The general average beard length is $12.46 \mathrm{~cm}$ in the dry test and $14.34 \mathrm{~cm}$ in the irrigated test. The DUNNET test showed no significant difference in the two trials.

\section{Ear neck length}

Analysis of variance indicates a low variability between genotypes. The effect of irrigation is demonstrated between the two treatments. The test DUNNET treating dry test distinguishes two homogeneous groups, the first one is formed by Chen's 'and Om Rabi 9 which are significantly superior to the control, the second group genotypes average significantly equal to the control. This test gathers all the studied genotypes with control into the same group in the irrigated test. Om Rabi 9 records the best length of the ear neck $(35 \mathrm{~cm})$ and $\mathrm{MB}$ Bachir records only $22.10 \mathrm{~cm}$.

\section{Last internode length}

No significant differences between the genotypes, however the lengths of the last internodes vary from $9.32 \mathrm{~cm}$ in Oued Zenati to $10.63 \mathrm{~cm}$ in Kabir with an average of $9.95 \mathrm{~cm}$ in dry test and from 11.67 $\mathrm{cm}$ in Kabir to $15.05 \mathrm{~cm}$ in MB Bachir with an average of $13.39 \mathrm{~cm}$ in irrigated test (Figure 3). The DUNNET test showed no significant differences in the two trials.

\section{The lifetime of the last leaf (senescence)}

The evolution of the senescence of the flag leaf of the six durum wheat genotypes was observed for four weeks in the month of May $(9,16,24$ and 30) and the notations brought out the graphs which define the lifetime of the flag leaves of each genotype. The curves show the effect of water stress on the leaf area particularly in Kabir, Chen's 'and BD 1/94. Senescence is more accelerated in dry tests than in irrigated ones (Table 8).

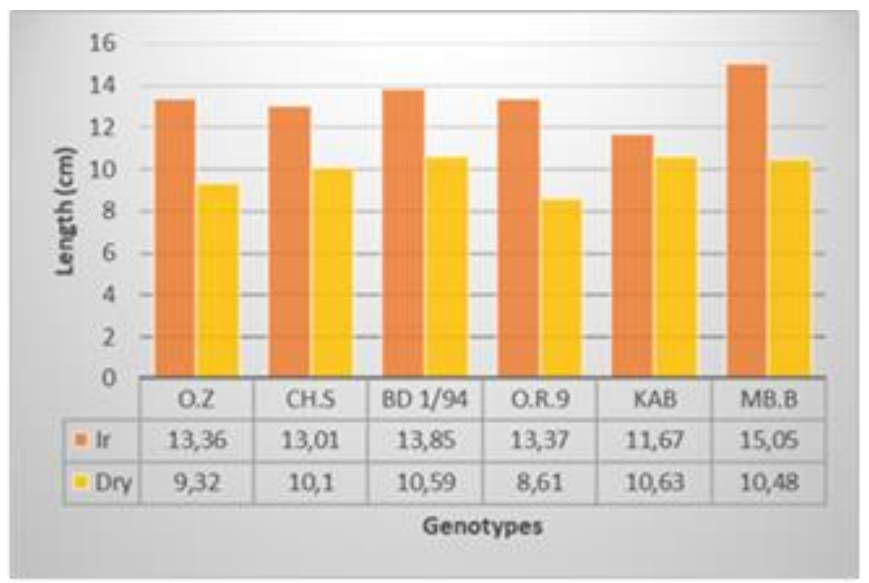

Figure 3. Last internode length $(\mathrm{cm})$ of the tested durum wheat genotypes under watered and nonwatered conditions

Table 8. Evolution of senescence of last leaves of the tested durum wheat genotypes under watered and non-watered conditions

\begin{tabular}{|c|c|c|c|c|c|c|c|}
\hline \multirow[t]{3}{*}{ Genotypes } & \multicolumn{7}{|c|}{ Averages \% } \\
\hline & \multicolumn{3}{|c|}{ Dry } & \multicolumn{4}{|c|}{ Irrigated } \\
\hline & $9 / 5$ & $16 / 5$ & $24 / 5$ & $1 / 9$ & $16 / 5$ & $24 / 5$ & $30 / 5$ \\
\hline Oued Zenati & 67.26 & 77.86 & 100 & 44.87 & 63.37 & 71.78 & 100 \\
\hline Chen's' & 64.72 & 98.33 & 100 & 83.81 & 92.40 & 100 & 100 \\
\hline BD 1/94 & 70.10 & 94.76 & 100 & 59.43 & 65.77 & 96.27 & 100 \\
\hline Om Rabi 9 & 50.89 & 74.96 & 100 & 32.93 & 62.44 & 85.58 & 100 \\
\hline Kabir & 79.80 & 93.00 & 100 & 69.89 & 73.97 & 83.03 & 100 \\
\hline M.B. Bachir & 45.90 & 66.48 & 100 & 49.23 & 62.11 & 86.08 & 100 \\
\hline
\end{tabular}

Days to heading. 


\section{Phenological traits}

Being sown on December 20, emergence was carried out on January 04 for all genotypes. The duration of the sowing-heading phase is on average 110.50 days in rainy conditions varying between 102.33 days for Chen's 'and 119.67 days for MB Bachir. This phase lasts an average of 114.89 days under irrigation conditions ranging from 105 days at Chen's 'to 123.67 days at MB Bachir. Oued Zenati and MB Bachir are therefore a late-heading genotype while Chen's 'which is a selected genotype has an early heading (Figure4).

\section{Days to maturity}

Maturity is reached after 164.78 days of sowing under rained conditions and after 169.06 days under irrigated conditions. The local genotypes MB Bachir and Oued Zenati have a late maturity. Chen's', BD 1/94 and Kabir matured early (Figure 5).

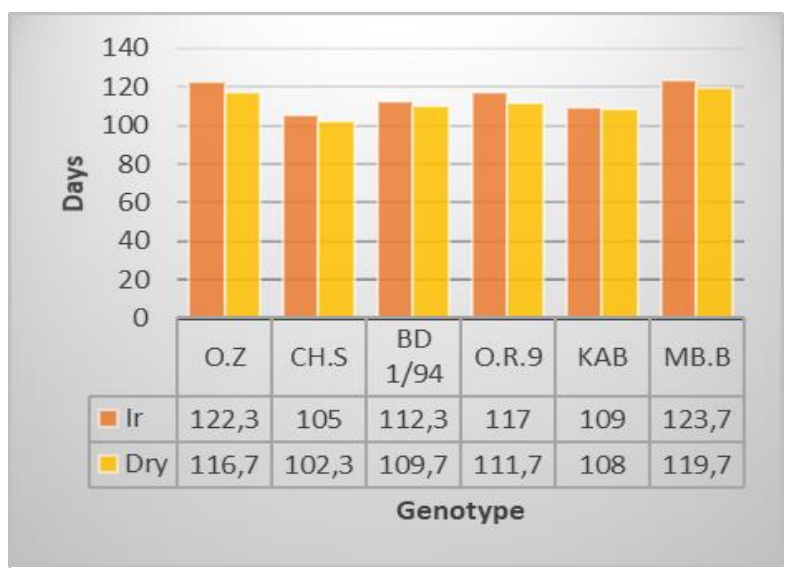

Figure 4. Days to heading of the tested durum wheat genotypes under watered and nonwatered conditions.

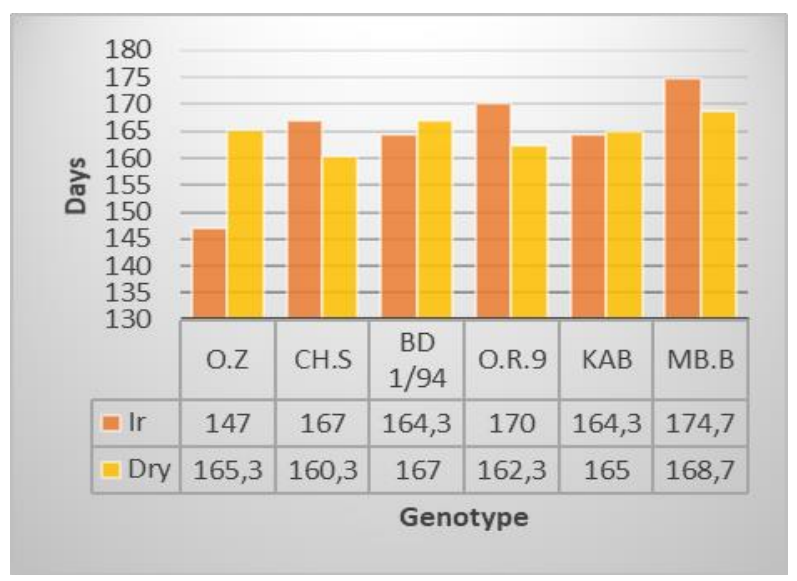

Figure 5. Days to maturity of the tested durum wheat genotypes under watered and non-watered conditions

\section{The yield components}

\section{Number of ears per $m^{2}$}

The ears of BD 1/94 are more numerous than those of other genotypes in rainy conditions. Chens had more ear per $\mathrm{m} 2$ under favorable conditions (Figure 6).

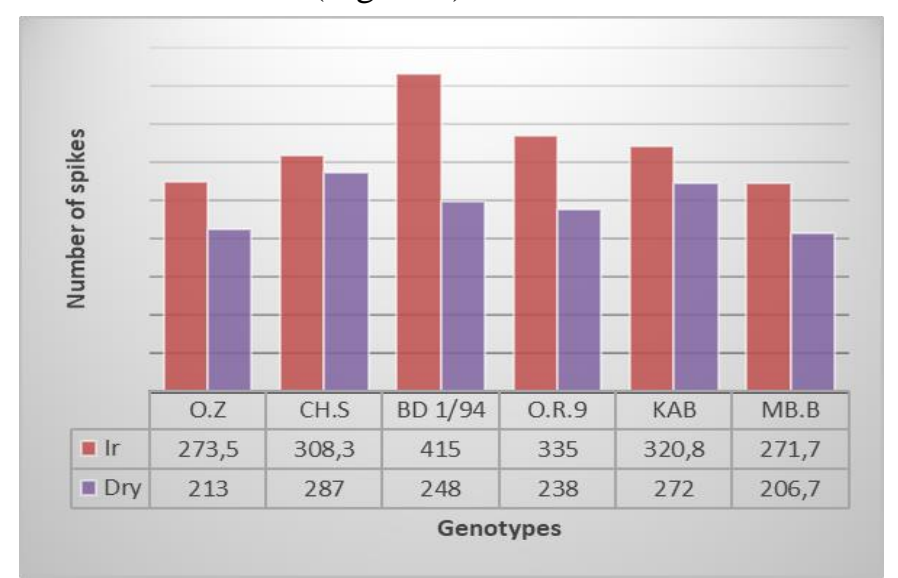

Figure 6. Number of ears per $\mathrm{m}^{2}$ the tested durum wheat genotypes under watered and non-watered conditions 
The number of ears per $\mathrm{m}^{2}$ is well correlated to the number of fertile spikelets $\left(\mathrm{r}^{2}=0.933\right)$ in drought conditions, these two characteristics are moderately correlated $\left(\mathrm{r}^{2}=0.571\right)$ in watered conditions (Figure 9). This trait is positively influenced by irrigation especially at $50 \%$ of field capacity. Also, an important correlation has been showed between the number of ears and the grain yield $\left(r^{2}=0.944\right)$ in dry and $\left(\mathrm{r}^{2}=0.723\right)$ in irrigated.

\section{The number of fertile spikelets per ear}

On average, there were 12.27 fertile spikelets per ear, varying between 9.47 in MB Bachir and 15.53 in Chen's 'under stress conditions. In irrigated conditions, the number varies between 12 for MB Bachir and 15.80 for Kabir with an average of 14.19 fertile spikelets per ear where all the genotypes produce spikelets as many fertile spikelets as the control (Table 9).

\section{The number of grains per ear}

The statistical treatment reveals a difference between the genotypes, the number of seeds per ear averages 23.74 under dry conditions, varies between 16.67 in MB Bachir and 30.60 in Chen's' whose ear, under irrigated conditions, contains 44.53 seeds. The irrigation effect is therefore verified in this measurement.

We note that in dry conditions, the selected genotype Chen's' produces long and very fertile ears followed by Om Rabi 9 which, although its ears are not as long as those of Chen's' or Kabir, they are very fertile, this is verified even under irrigated conditions although the effect of the water inputs is clearly determined, MB Bachir and Oued Zenati produce the lowest number of seeds per ear due to their small size.

Table 9. DUNNET test of fertile spikelets number per ear of the tested durum wheat genotypes under dry and watered conditions

\begin{tabular}{ll}
\multicolumn{2}{c}{ Fertile spikelets number per ear (N. irri.) } \\
\hline Genotypes & Averages \\
\hline Chen's' & $15.53 \quad>$ control \\
\hline Kabir & 13.33 \\
\hline Om Rabi 9 & 12.60 \\
\hline BD 1/94 & 11.60 \\
\hline Oued Zenati & $11.07=$ control \\
\hline M.B. Bachir & 9.47 \\
\hline
\end{tabular}

\begin{tabular}{ll}
\multicolumn{2}{c}{ Fertile spikelets per ear (Irrigated) } \\
\hline Genotypes & Averages \\
\hline Kabir & 15.80 \\
\hline Om Rabi 9 & 14.87 \\
\hline BD 1/94 & 14.67 \\
\hline Chen's' & 14.67 \\
\hline Oued Zenati & $13.13=$ control \\
\hline M.B. Bachir & 12.00 \\
\hline
\end{tabular}

The ears weight.

In drought conditions all genotypes belong to the same control group. The weight of their ears varies from $0.97 \mathrm{gr}$ in MB Bachir to 2.17 in BD 1/94 whereas in irrigated test, the average of this weight is $1.97 \mathrm{gr}$, Chen's produces ears weighing $2.55 \mathrm{gr}$, best weight of ears and MB Bachir produces the ears with the lowest weight.

\section{The weight of the kernels of 5 ears}

Chen's 'and Om Rabi 9 appear to have the best grain weights under irrigation and drought conditions. The statistical treatment indicates a low variability between the genotypes: from the lowest weight for Oued Zenati with 5.13 gr to the highest for Chen's' with 9.10 gr in dry conditions and the lowest for MB Bachir with $6.30 \mathrm{gr}$ at the highest with $10.80 \mathrm{gr}$ at Om Rabi 9 under irrigation conditions. The difference is therefore insignificant even between treatments. TGW (Thousand Grains Weight) will give more information for a more precise interpretation.

\section{The weight of a thousand grains}

Under water stress conditions the average weight of a thousand grains is $47.71 \mathrm{gr}$ varying between $41.60 \mathrm{gr}$ in Chen's' and $57 \mathrm{gr}$ in MB Bachir. Under irrigated conditions, the average is $50.90 \mathrm{gr}$ ranging from $44.09 \mathrm{gr}$ in Chen's' to $56.75 \mathrm{gr}$ in the control Oued Zenati. This later as local genotype in 
addition to M.B. Bachir and BD 1/94 as a selected one are therefore characterized by fairly large grains compared to the others.

\section{The biological yield}

The differences among the genotypes and between the treatments are significant. The average biological yield is $40.78 \mathrm{Qs} / \mathrm{Ha}$ in dry and $53.08 \mathrm{Qs} / \mathrm{Ha}$ in irrigated. M.B. Bachir have the lowest biological yield. Chen's 'and Oued Zenati gave the highest organic yield in dry and irrigated conditions. The selected genotypes Chen's 'and Kabir produce more straw than the others under dry conditions, while under irrigation conditions, Oued Zenati and BD 1/94 produce more straw (Fig 7).
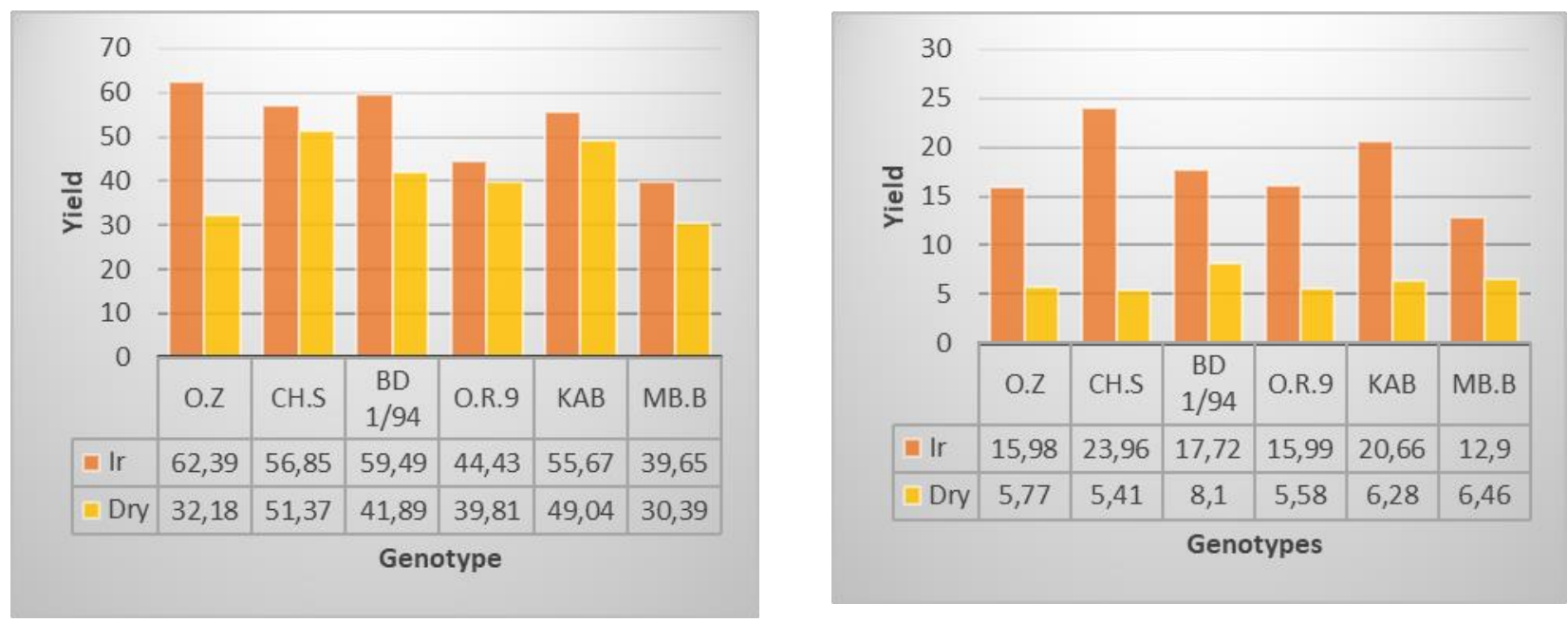

Figure 7. Biological and grain yields (Qs/ha) of the tested durum wheat genotypes under non watered and watered conditions

\section{Grain yield}

The statistical treatment shows a clearly significant difference among the varieties and between the treatments in terms of grain yield. This yield can be expressed as a function characterized by the environmental constraints and the adaptation characteristics related to the genotype: under drought conditions the average yield was 6.27 Qs / ha, Chen's' produced the lowest yield 5.41 Qs / ha and BD 1/94 gave the best yield with 8.10 Qs / ha. Under irrigation, the average is 17.70 Qs / ha, so an average gain of 11.43 Qs / ha. This gain in yield proves the positive effect of irrigation. M.B. Bachir gave the lowest yield with 12.90 Qs / ha and Chen's' produced the best grain yield with 23.96 Qs / ha (Fig 7). The two selected genotypes Chen's 'and BD 1/94 are significantly superior to the control. The rest are significantly equal to the control under both treatments (Figure 7; Table 10).

Table 10. DUNNET test of grain yield of the tested durum wheat genotypes under dry and watered conditions

Grain yield (Non irrigated)

\begin{tabular}{ll}
\hline Genotypes & Averages \\
\hline BD 1/94 & $8.10>$ control \\
\hline M.B. Bachir & 6.46 \\
\hline Kabir & 6.28 \\
\hline Oued Zenati & $5.77=$ control \\
\hline Om Rabi 9 & 5.58 \\
\hline Chen's' & 5.41 \\
\hline
\end{tabular}

Grain yield (Irrigated)

\begin{tabular}{ll}
\hline Genotypes & Averages \\
\hline Chen's' & $23.96>$ control \\
\hline Kabir & 20.66 \\
\hline BD 1/94 & 16.72 \\
\hline Om Rabi 9 & 15.99 \\
\hline Oued Zenati & $15.98=$ control \\
\hline M.B. Bachir & 12.90 \\
\hline
\end{tabular}




\section{The harvest index}

The harvest index is the ratio of grain yield to biological yield, it expresses the ability of each genotype to produce grain in relation to the total dry matter.

Chen's 'and Kabir which are improved genotypes produce the best yields if placed in favorable rainfall conditions. They are not adapted to water stress conditions. The local genotype M.B. Bachir seems to be adapted to water stress (Figure 8).

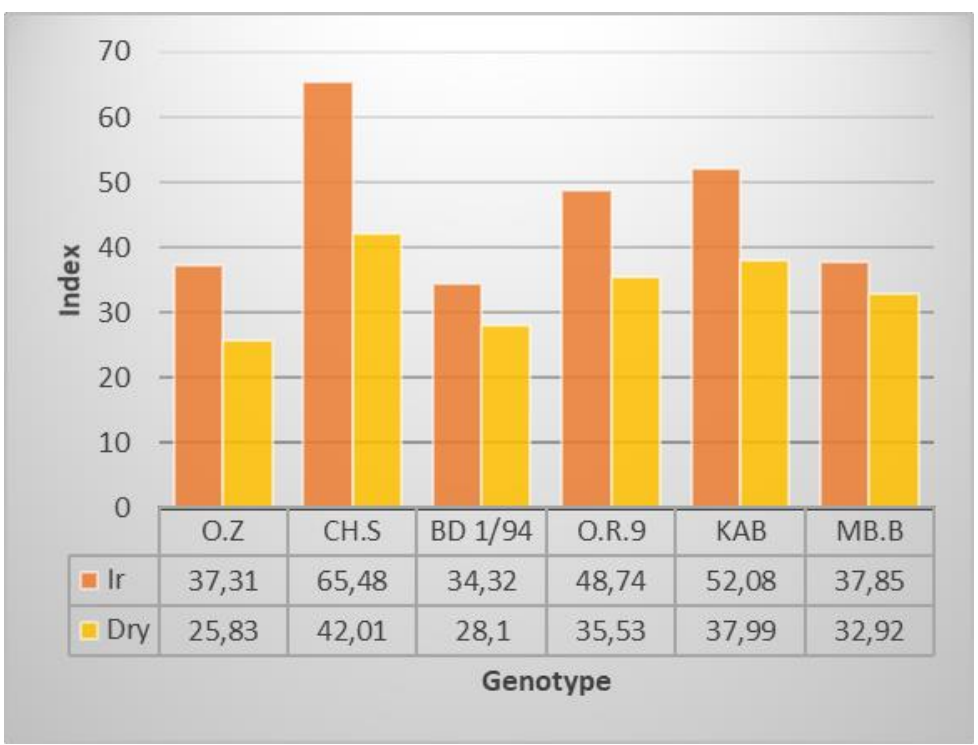

Figure 8. Harvest index of the tested durum wheat genotypes under dry and watered conditions

The following correlations were noted: in drought conditions, the number of seeds per ears is correlated with the number of fertile spikelets, the grain yield and not the length of the ear. While under irrigation conditions, the number of seeds correlates with the length of the ear, the number of fertile spikelets, the weight of the ears and the weight of the grains (Figure 9). Statistical analysis reveals important correlations, such as between heading and maturity (0.646) in dry test and (0.868) in irrigated one, between heading and TGW (0.762) in drought and (0.779) in watered, between maturity the weight of a thousand grains (0.933) in drought (Figure 9). Grain yield correlates with the number of fertile spikelets per ear under drought conditions (0.955). Biological yield is correlated with the number of fertile spikelets, the number of grains per ear and the weight of the ears under irrigation conditions. While under irrigation conditions, the harvest index is moderately correlated with the stand, the length of the ear and the weight of the grains, it is negatively correlated with the height, the length of the last internode, the weight of thousand kernels, the grain yield and the number of sowingheading days. Neck length, number of fertile spikelets, number of grains, ear weight and biological yield are correlate with the harvest index (Figure 9). 


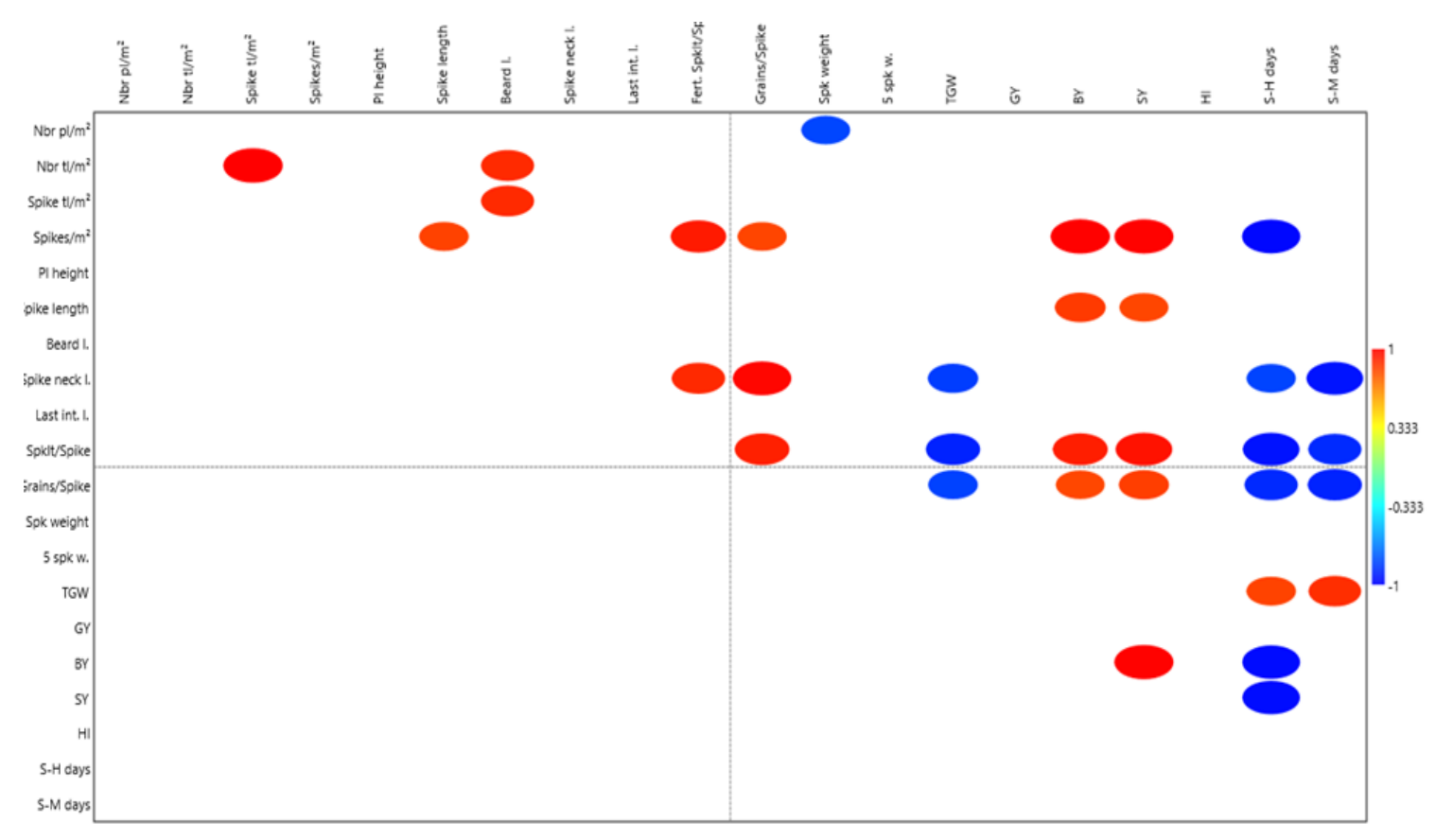

Figure 9. Correlation coefficients range from negative (blue) to positive (red), Non-significant coefficients are not taken in consideration, omitted using (White) color.

\section{Discussion}

The effect of water stress was measured on various phenological and morphological parameters as well as yield components in this study carried out by two treatments, one in rainy conditions and the other in irrigated conditions, to arrive to define the effect on six genotypes of durum wheat.

The analysis of rainfall data clearly reflects annual and inter-monthly variations. This campaign is characterized by a maximum rainfall in December $(53.30 \mathrm{~mm})$ and minimum in June $(4.57 \mathrm{~mm})$. The autumnal fall and winter conditions (implantation) explain the interannual variability of yields in the order of 60 to $65 \%$ (Couvreur, 85).

A drought sets in March and lasts for several months. This period is the most sensitive to drought, between the end of the booting stage and the milky grain stage. Indeed, at this stage, the plant cover presents a demand for water necessary for evapotranspiration. Wheat reacts to this demand by mechanisms affecting exchanges between the leaf and the atmosphere (stomatal regulation), which will contribute to limit the production of dry matter and therefore the yield. This deficit must be compensated by irrigation which constitutes a possibility of reducing this stomatal regulation (Fischer et al., 1998). For wheat crops, water stress during the early stages of development causes delayed and incomplete emergence which creates a defective and heterogeneous stand until harvest as well as poor and shallow root establishment (Amigues et al., 2006).

Note that it is irrigation at $50 \%$ of the field capacity which have the greatest influence on the stand. In general, the vegetative period from sowing to emergence is the period of establishment of the crop, water requirements during this period are moderate. The winter rainfall ensures this setting up. Knowing that our sowing was done on December 20 and emergence occurred on January 04, the water needs are still met by the rain. In addition, the establishment of the crop is conditioned by the texture of the soil, the precocity and the depth of sowing.

Water had a significant effect on the formation of the spike stand. We suppose that the water provided at tillering and booting stages is necessary for the formation of ears (ear stand). The selected genotype BD 1194 produces the best number of heads irrigated by $28 \mathrm{~mm}$ at tillering and $25 \mathrm{~mm}$ at booting. In general, the irrigation begins to be effective in the measurements of this parameter, it is from this 
period (booting-heading) that the wheat enters its sensitive phase, the drought affects considerably the components of the yield (rainfall $13 \mathrm{~mm}$ and irrigated by $25 \mathrm{~mm}$ on March 24). We notice a high rate of tiller regression. The number of potential heads is directly related to the density of plants and the amount of their herbaceous tillering. Indeed, only the most developed tillers (having at least three leaves and a root blank) will rise in a spike with the main stem and it is considered that the wheat must have two developed tillers at the end of the winter to obtain the desired ear stand (Couvreur, 1985). Beyond the $1 \mathrm{~cm}$ ear stage, a greater or lesser number of tillers will regress depending on the booting conditions.

Plant height is a useful physiological trait in breeding studies for the identification of stress tolerant genotypes under drought conditions (Mauman Shabbir et al., 2015; Pour-Aboughadareh et al., 2020; Khadka et al., 2020). The local genotypes Oued Zenati and M.B. Bachir have taller plants. It is noted that the highest straw yields obviously correspond to the highest heights.

The study of the number of grains per ears shows that the selected genotypes, in particular BD1/94 and Chen's' give long and fertile ears.

About the phenological traits, the notations on the heading and ripening dates reveal a difference which is due first to the genotype and to the climatic (water) conditions. We have precocious genotypes (Chen's 'and Kabir) and late genotypes (Oued Zenati and MB Bachir). BD 1/94 and Om Rabi 9 can be considered as being semi-precocious ones. Under drought conditions, BD 1/94 delays heading (109.67 days) and hastens maturity (167 days). This behavior is very interesting in so far as it allows the plant to escape both the risk of spring frosts and strong heat disturbing the translocation of assimilates and grain filling. In general, precocity is a phenomenon that influences the efficiency of water use. As mentioned by Megherbi et al. (2012), earliness in heading is also a desirable characteristic. This biological mechanism could be quantified by evasion since the early genotypes can complete their cycle, thus avoiding terminal drought. The important correlations revealed between heading and maturity in dry and irrigated test, between heading and TGW, and between maturity and TGW in drought let say that cycle shortening is a drought tolerant trait. A plant with an intermediate growing cycle is more drought-tolerant, which is the case of BD1 / 94. It should be noted that the weight of a thousand grains is positively influenced by irrigation and especially at $50 \%$ of the field capacity. According to Fellah and Hammena (2013), late material, because of its vernalization and photoperiodic requirements is not able to grow faster and to make the best use of the soil moisture available early in the season, while short cycle genotypes, such as waha do possess this ability because of its relative insensitivity to vernalization and to photoperiod. It developed a rapid leaf area early in the season, shading the soil surface, restricting water lost by evaporation, maximizing transpiration and improving the transpiration to evaporation ratio.

Yield levels vary according to water regimes, Ahmed et al. (2019) defined optimal water as $100 \%$ field capacity and stress as 50\% field capacity. Yield gains are highly significant in irrigated compared to drought conditions, but irrigation at $50 \%$ of the field capacity provides the best yields. The selected genotypes seem to be more productive in grains.

In general, the production period is a period of intense physiological activity, which goes from tillering to grain filling, it defined, the number of tillers, the number of ears and the number of grains per ear. The development of these components is linked to the enzymatic and physiological activity of which water is the main vector, the water requirements are therefore quite important. In fact, a lack of water during booting stage causes stoppage of tiller growth and a reduction in the number of heads per unit area (Kimurto et al. 2003).

The senescence of the flag leaf is well known as a criterion of tolerance to water deficit. This senescence was faster in Kabir, BD 1/94 and Oued Zenati in rainy conditions. Under irrigation conditions, Chen's 'proved too sensitive, M.B. Bachir and Om Rabi 9 were more resistant. We note that Om Rabi 9 is a resistant genotype in terms of yellowing of the last leaf. It seems that the green leaf area is negatively correlated with resistance to water deficit, the more this is reduced the better the avoidance of dehydration is better according to Borrell et al. (2000). 
Concerning yield traits, the climatic conditions during maturation are decisive in determining the weight of a thousand grains, the effect of irrigation is very important at this level. However, it should be known that an operator before heading can limit this weight by acting on the size of the grain envelopes (Couvreur, 1985). High above ground biomass could be achieved through faster early growth (Siddique et al., 1989). To get the best out of the water, it is necessary to increase the useful biomass of the plant where each part participates in the filling of the grains and consequently generates a weight of a thousand grains and a high yield (Riou, 1993). So, genotypes with the ability to grow faster early in the season, are able to avoid terminal drought and heat stress in Mediterranean environments as explained by Villagas et al. (2001). Although, increase in aerial biomass could be achieved through a longer cycle (under favorable environments), higher photosynthesis activity per unit leaf area or faster early growth (Slafer and Araus, 2007; Reynolds et al., 2009 and Del Pozo et al., 2016).

\section{Conclusion}

The results obtained during this study carried out on six genotypes of durum wheat allow us to highlight, if there was still needed, the effect of the water deficit on the different phases of the plant's life. The highlighted relationships are statistical relationships that we have tried to complete by focusing on certain causal links, taking into account several considerations such as the experimental protocol which must be very adjusted or, other parameters on which the yield will depend (soil preparation, fertilization, etc.). Nevertheless, it can be seen that a water deficit affects practically all the measured parameters. The so-called high-yield genotypes are those with long ears, a long neck, a large number of fertile spikes, a large number of grains per ear, a high ear weight and a high harvest index. A high thousand grains weight does not mean a good yield. The water deficit appreciably affects the height of the plants, the length and the weight of the spikes, these characteristics are directly related to the yield. Under favorable conditions (irrigation), the early or semi-early selected genotypes proved to be more productive and even adapted to the region's water stress. Late genotypes, although they consume water, meet the needs of farmers who combine animal husbandry with cereal crops. Earliness at heading and maturity are important factors in determining adaptation to water stress and in obtaining good yield. Moreover, as water is often not available, the type of irrigation, the volume (number of $\mathrm{mm}$ ) provided must be adjusted to the type of soil, and to the rainfall (supplementary irrigation) and especially at the vegetative stage where the yield component is the most critical. It seems to be the ear stand carried out at the bolting stage. The productivity of the durum wheat crop is imperatively based on the choice of a tolerant genotype to the conditions of the region on the one hand and on the use of supplementary irrigation and especially at the vegetative stage where the yield component is the most decisive, in our case it seems that it is the ear stand carried out at the booting stage.

\section{Acknowledgements}

Thanks are due to all the staff of the ITGC of Sidi Bel Abbes for their kindness.

Acknowledgment, respect and gratitude to the soul of Pr BENSEDDIK, God welcome him in his paradise.

\section{Funding Information}

This study was not funded by any sources 
Fetati et al. 2021. Genet. Biodiv. J, Special issue (Characterization and valorisation of Plants), 77-92

\section{References}

Ahmed HGMD. Sajjad M. Li M. Azmat MA. Rizwan M. Maqsood RH 2019. Selection criteria for drought-tolerant bread wheat genotypes at seedling stage. Sustainability 11:2584. doi: 10.3390/su11092584.

Amigues JP. Debaeke BI. Lemaire G. Seguin B Tardieu F., Thomas A 2006. Sécheresse et agriculture. Réduire la vulnérabilité de l'agriculture à un risque accru de manque d'eau. Expertise scientifique collective, synthèse du rapport, INRA (France), 72p.

Belaid A. Hadjel M. Hassini N 2012. Effects of drought on winter wheat yields in a semi-arid region, Water resources and wetlands, Editors: Petre Gâştescu, William Lewis Jr., Petre Breţcan. Conference Proceedings, 14-16 September 2012, Tulcea - Romania.

Borrell AK. Hammer GL. Douglas ACL 2000. Does Maintaining Green Leaf Area in Sorghum Improve Yield under Drought? I. Leaf Growth and Senescence. CROP PHYSIOLOGY \& METABOLISM. Crop Sci. 40:1026-1037.

Boussakouran A. Sakar Eh. El Yamani M. Rharrabti Y. 2019. Morphological Traits Associated with Drought Stress Tolerance in Six Moroccan Durum Wheat Varieties Released Between 1984 and 2007. J. Crop Sci. Biotech. (4): 345 353 DOI No. 10.1007/s12892-019-0138-0.

Couvreur F 1985. Formation du rendement du blé et risques climatiques. Pers agri. $n^{\circ}$ 95. pp 12-19.

Del Pozo A. Yáñez A. Matus IA. Tapia G. Castillo D. Sanchez-Jardón L. and Araus JL 2016. Physiological Traits Associated with Wheat Yield Potential and Performance under Water-Stress in a Mediterranean Environment. Front. Plant Sci. 7:987.

El Hafid R. Smith DAN H. Karrou M. Samir K 1998. Physiological Responses of Spring Durum Wheat Cultivars to Early-season Drought in a Mediterranean Environment. Annals of Botany Vol. 81, No. 2, pp. 363-370.

Fellah S. Hamenna B 2013. Variation in early growth, canopy temperature, translocation and yeald of durum wheat (triticum turgidum L. ar. Durum) under semi arid conditions. / Procedia - Social and Behavioral Sciences 1063291 - 3296.

Fischer RA. Rees D. Sayre KD. Lu ZM. Condon AG. Saavedra AL 1998. Wheat yield progress associated with higher stomatal conductance and photosynthetic rate and cooler canopies. Crop Sci. 38:1467-1475.

Hacini N. Brinis L 2012. Utilisation de quelques marqueurs physiologiques et biochimiques dans l'expression de tolérance au stress hydrique chez 10 génotypes de blé dur (Triticum durum Desf.). Rev. Sci. Technol., Synthèse 25: 6- 16.

Honsdorf N. Verhulst N. Crossa J. Vargas M. Govaerts B.Ammar K 2020. Durum wheat selection under zero tillage increases early vigor and is neutral to yield. Field Crops Research, 248, 107675.

Hsissou D. Bouharmont J 1994. In vitro selection and characterization of drought-tolerant plants of durum wheat (Triticum durum Desf). Agronomie, EDP Sciences, 14 (2), pp.65-70. ffhal$00885612 \mathrm{f}$.

Khadka K. Earl HJ. Raizada MN. Navabi A 2020. A Physio-Morphological Trait-Based Approach for Breeding Drought Tolerant Wheat. Front. Plant Sci. 11:715. doi: 10.3389/fpls.2020.00715.

Kimurto PK. Kinyua MG. Njoroge JM 2003. Response of bread wheat genotypes to drought simulation under a mobile rain shelter in Kenya, African Crop Sci. J., Vol.11, 225-234.

Mauman Shabbir R. Yacin Ashraf M. Waraich EA. Ahmad R. Shahbaz 2015. Pak. J. Bot., 47(4): 1207-1216.

Mefti M. Abdelguerfi A. Chebouti A 2000. Etude de la tolérance à la sécheresse chez quelques populations de Medicago truncatula (L.) Gaertn. Options Mediterraneennes CIHEAM, 2000, 173176.

Megherbi A. Mehdadi Z. Toumi F. Moueddene K. Bachir Bouadjra SD 2012. Tolérance à la sécheresse du blé dur (Triticum durum Desf.) et identification des paramètres morphophysiologiques d'adaptation dans la région de Sidi Bel-Abbès (Algérie occidentale), Acta Botanica Gallica, 159:1, 137-143.

Mekhlouf A. Bouzerzour H. Benmahammed A. Hadj Sahraoui A. Harkati N 2006. Adaptation 
des variétés de blé dur (Triticum durum Desf.) au climat semi-aride. Sécheresse ; 17 (4) : 507-13. doi: 10.1684/sec.2006.0054.

Monneveux P. Jing R. Misra SC 2012. Phenotyping for drought adaptation in wheat using physiological traits. Front Physiol. 3: 429. doi: 10.3389/fphys.2012.00429.

Pour-Aboughadareh A. Mohammadi R. Etminan A. Shooshtari L. Maleki-Tabrizi N. Poczai P 2020. Effects of Drought Stress on Some Agronomic and Morpho-Physiological Traits in Durum Wheat Genotypes. Sustainability 2020, 12, 5610; doi: 10.3390/su12145610.

Reynolds M. Foulkes MJ. Slafer GA. Berry P. Parry MAJ. Snape John W. Angus WJ 2009. Raising yield potential in wheat. Journal of Experimental Botany, Vol. 60, No. 7, pp. 1899-1918.

Riou C. 1993. L'eau et la production végétale. Sécheresse, 4: 75 - 83.

Siddique KIfM. Belfbrd RK. Perry MW. Tennant D 1989. Growth, Development and Light Interception of Old and Modern Wheat Cultivars in a Mediterranean-type Environment. Aust. J. Agric. Res., 1989, 40, 473-87.

Slafer G. Araus JL 2007. Physiological Traits for Improving Wheat Yield Under a Wide Range of Conditions. J.H.J. Spiertz, P.C. Struik and H.H. van Laar (eds.), Scale and Complexity in Plant Systems Research: Gene-Plant-Crop Relations, 147-156.

Talebi R. Fayaz F. Naji AM 2009. Effective selection criteria for assessing drought stress tolerance in durum wheat (Triticum durum Desf.). General and Applied Plant Physiology, Volume 35 (1-2), pp. 64-74.

Villagas D. Aparicio N. Blanco R. Royo C 2001. Biomass accumulation and main stem elongation of durum wheat grown under Mediterranean conditions. Annals of Botany 88: 617-627. 